\title{
CUMULATIVE INDEX
}

\section{Volumes I-XII}

\section{SUBJECT MATTER INDEX}

VOLUME \& PAGE

\section{ADMINISTRATIVE LAW}

Insurance Regulation in Alaska: Healthy EXercise of a State

Perogattve ............................................. 10:279

Mandatory Miediation of Coastal Zone Planning Disputes in Alaska-AN

INNOVATIVE APPROACH TO ADMTISTRATTVE DECISIONMAKING ............. 1:349

Mental Health Land Trust Litigation: State $v$. Weiss and Its Aftermatr, THE.

\section{ADMIRALTY}

Analysis of Jurisdictional Issues Presented When State-Employed

SEAMEN ARE INJUREd AND SEEK REDRESS, AN ..................... 8:203

ALASKA NATIVES

CATHolic Soctal SERVICES, INC V. C.A.A.: Best Interests and Statutory Construction of the Indian Child Welfare Act $\ldots \ldots \ldots \ldots \ldots \ldots \ldots \ldots .7: 203$

Foreword to Native Law Selections: Recent Develodments in Federal Indian Law as Applied to Native Alaskans .................... 10:333

IndLan Child Welfare Act: Does It Cover Custody Disputes Among EXTENDED FAMILY MEMBERs?, THE ........................... 1:157

Tribal Court Jurisdiction and Public Law 280: What Role for Tribal Courts In Alaska ....................................... 10:335

Tribal Powers to Regulate Hunting in Alaska ................... 4:223

WaIVer of Tribal SOVereign IMmunity IN THE Contractual Context: Conflict Between the Ninth Circuit and the Alaska Supreme Court? .. 10:363

When Worlds Collide: Alaska Native Corporations and the Bankruptcy CODE

\section{ALTERNATIVE DISPUTE RESOLUTION}

Alaska's Medical Malpractice Expert Advisory Panel: Assessing the

Prognosis.............................................. 9:401

Alternative Dispute Resolution Strategies in Medical Malpractice . . . . 9: 9:429

\section{BANKRUPTCY}

In Re Copper RIVER SChOOL District. Collective Bargaining and Chapter

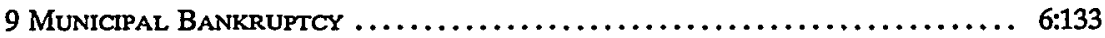

When Worlds Collide: Alaska Native Corporations and the BankRuptcy

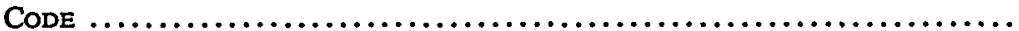

\section{CIVIL PROCEDURE}

Alaska Rule of Civil Procedure 11: A Proposed Amendment and a Guide FOR APPLICATION AND INTERPRETATION 
Civil Rule 90.3: Judictal Discretion Under Alaska's ChILd Support GuIDELINE........................................... 8:251

COMPULSORY JOINDER OF PARTIAL SUBROgeES: IMPLICATION OF tHE ALASKA

RulE................................................ 1:171

ENFORCEABILITY OF FORUM-SELECTION CLAUSES AFTER STEWART ORGANIZATION, INC V. RICOH CORPORATION, THE .................... 6:175

IMPACT OF ECONOMIC INCENTIVES ON THE AWARD OF ATTORNEY'S FEES IN

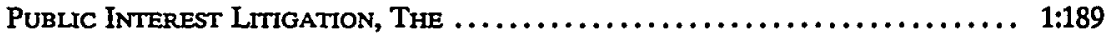

LaWrence v. LAWRence: The Use of Rule 60(B) Motions Based Upon Post

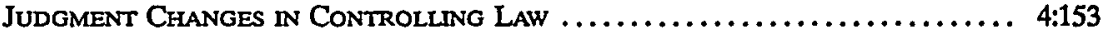

Limgation-Ending Sanctions: Alaska Courts' Use of Rule $37 \ldots \ldots \ldots \ldots . .2: 77$

Preliminary Iinunnctions as Relief for Substtantial Procedural Violations o f EnVIRONMENTAL Statutes: Amoco Production Co. $v$.

VILLAGE OF GAMBBELL ................................... 4:105

Rule 82 Revisited: Attroney Fee Shifting in Alaska $\ldots \ldots \ldots \ldots \ldots \ldots \ldots . . \ldots 10: 429$

COMMERCIAL LAW

Alaska Distress law in the Commercial Context: Ancient Relic or

FunCTIONAL REMEDY? ..................................... 10:33

RILEY v. Northern COMmercial- COMmerclal Rationale TruUmphs Over

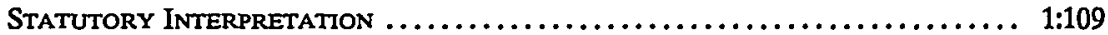

\section{CONSTITUTIONAL LAW}

Alaska's Criminalization of Refusal to Take a Breath Test: Is it a

Permissible Warrantless Search Under the Fourth Amendment? .......

Alaska Pacific Insurance Co. v. Brown: The Right to Travel and the

CONSTITUTIONALITY OF CONTINUOUS RESIDENCY REOUIREMENTS ...

Alaska's Right to Privacy Ten Years After Ravin v. State. Developino a

JURISPRUDENCE OF PRIVACY ................................. 2:159

"Be it Enacted by the People of the State of Alaska. .." - A

Practitioner's Guide to Alaska's Initiative LaW ..................

Compelling Testmmony in Alaska: The Coming Rejection of Use and

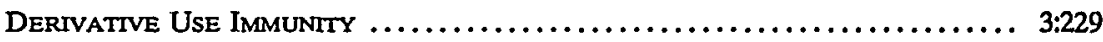

ConstTtutionaltTy OF SOBRIETY CHECKPOINTS IN Al_aska, THE ............ 8:227

Custodial Consents to Search in Alaska: A Watver Approach, at least

Where Miranda Warnings Are Absent? ....................... 3:125

Drug Testing of Public and Private Employees in Alaska ............. 5:133

Freedom of Religion in Alaska: INTERPRETING the Alaska Constitution ... 5:237

Investigative Stops in Alaska: Can Coleman SuRvive a Multifactored

BaLANCE? ........................................ 7:381

Local Hire LaWs: Alaska's Futtle Attempts at Preferential Treatment .. 4:359

Northern Lights-Equal Protection Analysis in Alaska ............. $3: 1$

Police Deception of a Criminal Suspect's Attorney: An Analysis of

Moran V. BURbine Under the Alaska Constitution................ 5:161

Private Rights Versus Public Power: The Role of State Action in Alaska

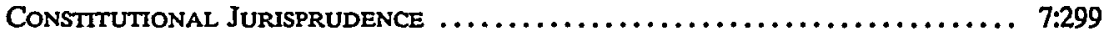

Protection of Child Witinesses and the Rioht of Confrontation: A

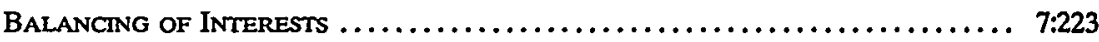

RESTITUTION, RETRIBUTION, AND THE CONSTITUTION ................. 7:333

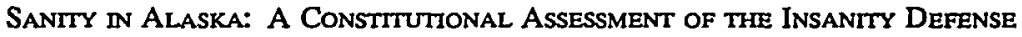

Statute............................................ 10:65

Standards of MaterialtTy Governing the Prosecutorial Duty to

Disclose Evidence to the Defense ......................... 6:147

Tale of Two Courts: The Alaska Supreme Court, The United States

SUPREME COURT, AND RETROACTIVITY $\ldots \ldots \ldots \ldots \ldots \ldots \ldots \ldots \ldots \ldots \ldots . . \ldots$ 9:305 
CONSTITUTION-ALASKA

Alaska's Right to Privacy Ten years After Ravin v. State. Developing a

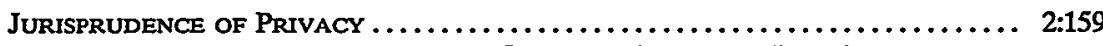

"Be it Enacted by the People of the State of Alaska. . ." - A

Practimioner's Guide to Alaska's InITIATtVe LaW .................. 9:279

Drug Testing of Public and Private Employees in Alaska ............. 5:133

Freedom of Religion in Alaska: Interpreting the Alaska Constitution ... 5:237

local Hire Laws: Alaska's Futile Attempts at Preferential Treatment .. 4:359

Police Deception of a Criminal Suspect's Attorney: An Analysis of

Moran v. BURbine Under the Alaska Constitution................ 5:161

Privacy vs. Practicality: Should Alaska Adopt the Leon Good Fatth

EXCEPTION?........................................... 10:143

Tale of Two Courts: The Alaska Supreme Court, The United States

SUPREME Court, AND RETROACTIVITY ......................... 9:305

Welcome to the "LAST Frontier," Professor GardNer: Alaska's

INDEPENDENT APPROACH TO STATE CONSTTTUTIONAL INTERPRETȦTION.........

Self-InCRIMINATION Protection Under the Alaska Constitution: A

DESCRIPTIVE ANALYSIS.....................................

\section{CONTRACTS}

Alaska's Public Duty Exception: Restratnts Upon the Right to

CONTRACTUAL INDEMNITY.

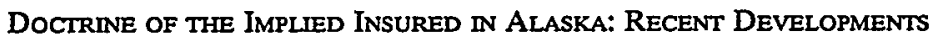

Concerning Third Parties to Insurance Contracts, The

ENForceability of Forum-Selection Clauses After STEWART

ORGANIZATION, INC V. RICOH CORPORATION, THE

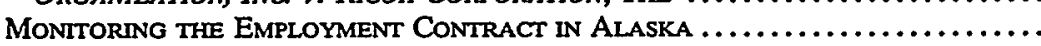

MUNICIPALITY OF ANCHORAGE V. HITACHI CABLE, LTD.-TIME FOR ADOPTION OF

a VoId Contract Remedy for Alaska Public Contracting Authorities..

\section{CORPORATE LAW}

Alaska Corporations Code: The Forty-Ninth State Claims the Mmdle

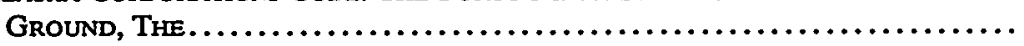

Control and/or Misconduct: Clarifying the Test for Piercing the

Corporate Veil in Alaska ............................... $9: 65$

Creation, Operation, and Dissolution of a Limited Partnership in

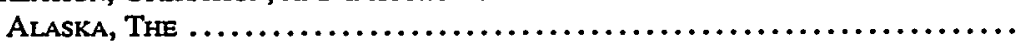

Shareholders' Agreements in Alaska After Hikita v. NiCHIro Gyogyo

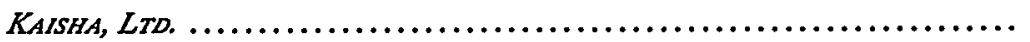

CRIMINAL LAW

Alaska's Insantty Defense and the "Guilty But Mentally Ill" Verdict...

Alaska's MENS Rea ReQuirements For StATUtory RAPE $\ldots \ldots \ldots \ldots \ldots \ldots \ldots$

Consciousness of WRONGdoIng: MENS REA In Al.ASKa $\ldots \ldots \ldots \ldots \ldots \ldots \ldots \ldots$

Development of Appellate Sentencting Law in Alaska, The..............

LeSSER-INCLUded OfFenses In Alaska: STATE $v$. MiNANO .................

NITZ V. STATE: SkeWIng the Evidentiary Rules to Prosecute ChIID

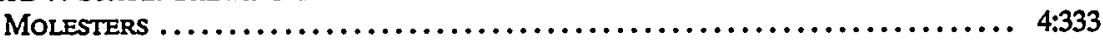

OVerview of Juventle Delinguency LaW in Alaska, AN ............. $8: 1$

PEARS V. STATE: AN IMPROPER APPLICATION Of ALASKa's CuRrent LAW to

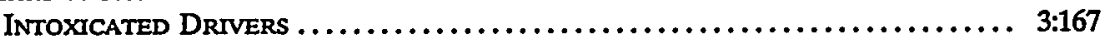

Post-Plea APPEAL OF “Dispostive” IsSues: “There's Glory For You!” . . . . 5:221

Presumptive Sentencing in Alaska $\ldots \ldots \ldots \ldots \ldots \ldots \ldots \ldots \ldots \ldots \ldots \ldots \ldots \ldots .2: 227$

Re-Evaluation of Alaska's Plea Bargaining Ban, A $\ldots \ldots \ldots \ldots \ldots \ldots \ldots \ldots$. $8: 27$

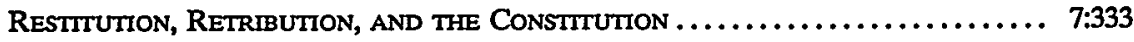


Standards of Materialtiy Governing the Prosecutorial Duty to

Disclose EVIDENCE TO THE DEFENSE

CRIMINAL PROCEDURE

Admissibility of Prior Bad Acts in Sexual Assault Cases Under Alaska

Rule of Evidence 404(B)-AN EMerging Double Standard, The ........ 5:193

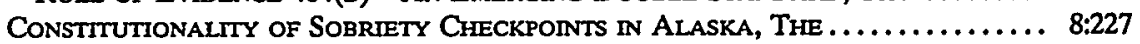

Custodial Consents to Search in Alaska: A Waiver Approach, at least

Where Miranda Warnings Are Absent? ........................ 3:125

DeterRing Defendants from TAxing the Stand: The Extension of STATE $v$.

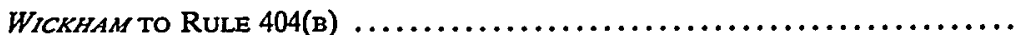

Development of Appellate Sentencing Law in Alaska, The ............ 7:265

INCONSISTENT JURY VERDICTS RETURNED ON A MULTIPLE COUNT INDICTMENT OF

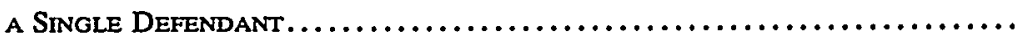

Investigative Stops in Alaska: Can Coleman Survive a Multifactored

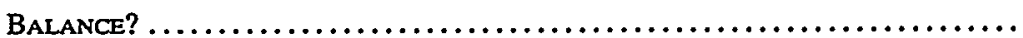

Police Deception of a CRImINal Suspect's Attorney: An ANAlysis of

MORAN V. BURBINE UNDER THE Alaska ConstitutION...................

Post-Plea Appeal of "Dispositive" Issues: "There's Glory For Youl" ......

Privacy vs. Practicality: Should Alaska Adopt the Leon Good Farth

ExcEPTION?............................................. 10:143

Protection of ChILd Witnesses and the Right of Confrontation: A

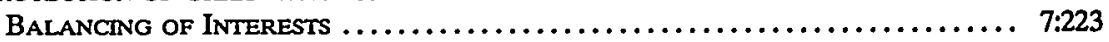

Re-Evaluation of Alaska's Plea Bargaining Ban, A ............... $8: 27$

Reportorial Power of the Alaska Grand JuRy, The ................. $3: 295$

RETHINKING MANIFEST INJUSTICE: ReFlections UPON THE DECISIONS OF THE

Three-Judge Sentencing Panel.............................

SANTTY In Alaska: A Constitutional AsSEsSment of the INSANITY Defense

STATUTE .......................................... 10:65

Standards of Materiality Governing the Prosecutorial Duty to

Disclose EVIDENCE TO THE DEFENSE

DUE PROCESS, COMMON LAW

Alaska's "Quasi Public" Hospitals: The Implication of StorRs...........

\section{EDUCATION}

Alaska Supreme Court and the Rights of Public School Teachers as

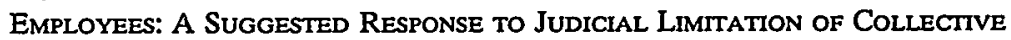

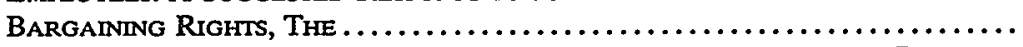

In Re Copper RIVER SCHOOL District. Collective Bargaining and Chapter

9 MUNICIPAL BANKRUPTCY .................................

\section{EMPLOYMENT}

Alaska Supreme Court and the Rights of Public School Teachers as EMPloyees: A Suggested Response to Judictal Limitation of Collective

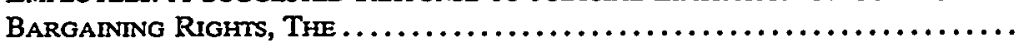

Bad Samaritans Make Dangerous Precedent: The Perils of Holdino an

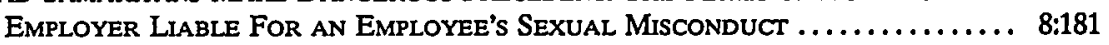

Drug testing of Public and Private Employees in Alaska.............. 5:133

Employment at Will in Alaska: The Question of Public Policy Torts . . . . . 6:269

EMPLOYMENT AT WILL: THE "AMERICAN RULE" aNd ITS APPLICATION IN

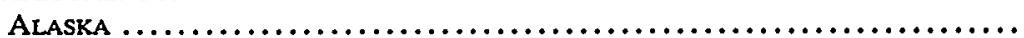

Employment Discrimination law-STRand v. PETERsbURg Public SChool AND FRIDRIXSSON V. ALASKA USA FEDERAL CREDIT UNION. THE SUPREME Court Charts an Uncertain Course $\ldots \ldots \ldots \ldots \ldots \ldots \ldots \ldots \ldots \ldots \ldots$ 
VOLUME \& PAGE

In Re Copper RIVER School District. Collective Bargaining AND Chapter

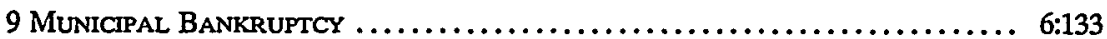

Local Hire Laws: Alaska's Futile Attempts at Preferential Treatment .. 4:359

MONITORING THE EMPLOYMENT CONTRACT IN ALASKA $\ldots \ldots \ldots \ldots \ldots \ldots \ldots \ldots .6 \%$

Shelter From the Storm: The NEED for Wrongful Discharge Legislation In Alaska ............................................ 6:321

SOMETHING MORE IMPORTANT ThAN MONEY-VOCATIONAL REHABILITATION IN Worker's Compensation CASES $\ldots . \ldots \ldots \ldots \ldots \ldots \ldots \ldots \ldots \ldots \ldots \ldots \ldots . \quad 3: 49$

StRICT LIABILITY AND THE ADMISSIBILITY OF EVIDENCE OF SUBSEQUENT

Remedial Measures Under Evidence Rule 407 ................... 5:333

THOMAS V. ANCHORAGE TELEPHONE UTILTTY. Alaska Tackles Gender-Based

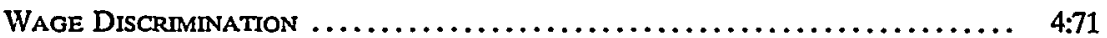

WaLt-Zing Through an EMployment Termination: Is There A DUTY to InVEstigate Before Discharging In Alaska? ..................... 11:231

\section{ENVIRONMENTAL LAW}

Amoco Production Co. V. VILLAGE OF GaMbeLL AND MOTOR VeHICLE MANUFACTURERS ASSOCIATION V. STATE FARM MUTUAL AUTOMOBILE INSURANCE CO.: AUTHORITY WARRANTING RECONSIDERATION OF THE Substantive Goals of the National Environmental Policy Act ....... 5:15 "Equal Access" to Alaska's Fish and WiLdLIFE................... 11:277 HAMMOND V. NORTH SLOPE BOROUGH. THE ENDANGERED SPECIES ISSUE-AN

EXERCISE IN JUdicial LETHARGY ................................ 1:129

High Stakes in the High ARctic JuRisdiction AND COMPENSATION FOR OIL

Pollution from Offshore Operattons in the Beaufort SEA............ Major Issues in Developing Alaska's Outer Continental Shelf OIL and

Gas Resources........................................ 1:209

Managing SenstTive Ecosystems: Honsinger V. STATE AND tHe NeEd for

FLEXIBILITY IN THE RULES OF ReAl PROPERTY .......................

Mandatory Mediation of Costal Zone Planning Disputes in Alaska-An INNOVATIVE APPROACH TO ADMINISTRATTVE DecisionMAKING ............. 1:349

Preliminary InJUNCtions as Relief for Substantlal Procedural

Violations of ENVIRONMENTAL StatuTES: AMOCO Productjon Co. $v$.

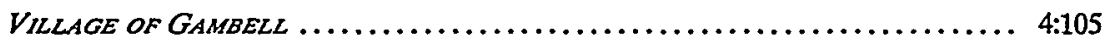

StrugGle for Alaska's SubMerged LAND, THE ................... $5: 69$

\section{EVIDENCE}

Admissibility of Prior Bad Acts in Sexual Assault Cases Under Alaska

Rule of Evidence 404(B)-An EMerging Double Standard ........... 5:193

Construction and Admissibility of Insurance Policies That Provide

Coverage for Punitive Damage Awards, The .....................

Deterring Defendants From Taking The Stand: The Extension of State $v$.

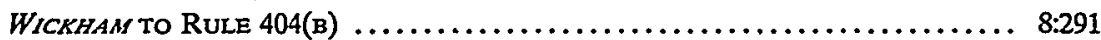

InSPECTION AND DISCOVERY OF StATE RECORdS IN ALASKa ............... 4:277

NITZ v. STATE. SKewIng the Evidentiary Rules to Prosecute ChILD

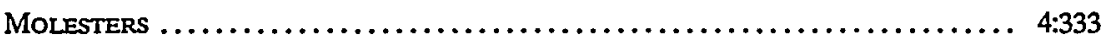

Standards of MAteriality Governing THE Prosecutorial DUTY to

Disclose Evidence to the Defense $\ldots \ldots \ldots \ldots \ldots \ldots \ldots \ldots \ldots \ldots \ldots \ldots \ldots . \ldots \ldots \ldots \ldots$

STRICT LIABILITY AND THE ADMTSSIBIITTY OF EVIDENCE OF SUBSEQUENT

Remedial Measures Under EVIDENCE RULE $407 \ldots \ldots \ldots \ldots \ldots \ldots \ldots \ldots$

\section{FAMILY LAW}

Abandonment v. Adoption. Terminating Parental Rights and the Need For Distinct Legal INQUIRIES $\ldots \ldots \ldots \ldots \ldots \ldots \ldots \ldots \ldots \ldots \ldots \ldots \ldots \ldots$ 
Catholic Soctal SERvices, INC V. C.A.A.: Best INTEREsts ANd Statutory

Construction of the Indian CHILD Welfare Act ................. 7:203

Ctull Rule 90.3: Judicial Discretion Under Alaska's ChILd Support

GuIDELINE............................................ 8:251

OVERVIEW of JuVENILE Delinguency LaW IN Alaska, AN ............. $8: 1$

Indian Child Welfare Act: Does It Cover Custody Disputes Amono

EXTENDED FAMLY MEMBERs? ............................... 1:157

NELSON V. NELLON: A PROPOSAL For EOUTtable Distribution of THE

Professional Degree $6: 345$

Protection of ChIld Witnesses and The Right of Confrontation: $A$

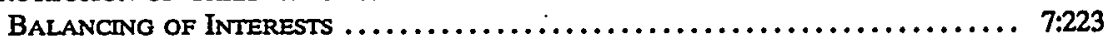

Visitation RIGHTS For NATURAI Parents AFter Stepparent Adoption ...... 1:319

Wanberg v. Wanberg. Characterization of Property for the Purpose of

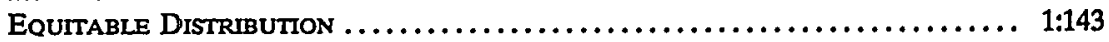

FEDERALISM

Tale of Two Courts: The Alaska Supreme Court, The United States

SUPREME COURT, AND RETROACTIVTTY ........................ 9:305

\section{FISHERIES}

Major Issues in Developing Alaska's Outer Continental Shelf OIl and

GAS RESOURCES...........................................

HOSPITALS

Alaska's "Quasi Public" Hospitals: The Implication of StorRs.......... 2:185

Eidelson v. ARCher. Exhiaustion of Remedies in a Private Hospital ....... 1:277

INDIAN POLICY

(See ALASKA NATIVES)

INSURANCE LAW

Construction and Admissability of Insurance Policies That Provide

Coverage for Puntitue Damage Awards, The ...................

Doctrine of THE IMPLIEd INSUREd IN ALASKa: RECENT DEVELOPMENTS

Concerning Third Parties to Insurance Contracts, The ............. 3:145

INSURANCE REGULATION IN Alaska: Healthy EXERCISE of a State

Perogattve ............................................ 10:279

One Climent, One Defense: Revisiting $C H I$ with the Alaska Rules of

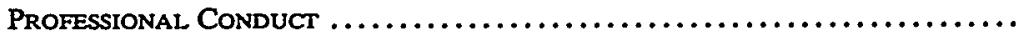

\section{JURIES}

INCONSISTENT JURY VERDICTS RETURNED ON A MULTTPLE COUNT INDICTMENT OF

A Single Defendant........................................ $3: 387$

REPORTORIAL POWER of the Alaska Grand JuRY, The .............. 3:295

JUVNILES

Overview of Juvenile Delinouency LaW in Alaska, An ................

LABOR LAW

Local Hire Laws: Alaska's Futtle Attempts at Preferential Treatment .. 4:359

\section{LEGAL PROFESSION}

ADOPTION OF THE ABA STANDARDS FOR IMPOSING LAWYER SANCTIONS BY THE Alaska Supreme Court-IN RE BUCKALEW, The

Alaska Rule of Civil Procedure 11: A Proposed Amendment and a Guide FOR APPLICATION AND INTERPRETATION 
IMPACT OF ECONOMT INCENTIVES ON THE AWARD OF ATTORNEY'S FEES IN

Public INTEREST Litigation, THE

VOLUME \& PAGE

Statute of Limitations for Professional Malpractice in Alaska After

LEE HOUSTON \& AsSOCIATES, LTD. V. RACINE, THE

OIL AND GAS

Major Issues in Developing Alaska's Outer Continental Shelf OIL and

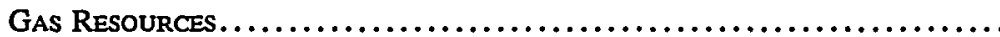

\section{POLITICAL PROCESS}

ASPEN EXPLORATION CORP. v. SHEFFIELD: The Status OF OfFICIAL IMMUNTTY IN AlASKA ............................................... 7:187

MEINERs V. Betring Strait SCHOOL District AND the Recall of Public Officers: A Proposal for Legislative Reform $\ldots \ldots \ldots \ldots \ldots \ldots \ldots \ldots$

Prison Overcrowding in Alaska: A Legislative Response to the Cleary SETTLEMENT

\section{PROPERTY}

Alaska Distress LaW in the Commercial Context. ANCIENT Relic or

FunCTIONAL REMEDY? ...................................... 10:33

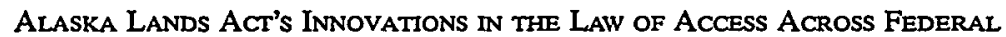

Lands: You $C_{A N}$ Get There From Here, The.....................

Clouds are lifting: The Problem of Title to Submerged lands in Alaska,

THE.

Easement Condemnation and STate $v$. DOYLE: Fair Market Value

WITHOUT A MARKET.

MANAGING SENSTTIVE ECOSYSTEMS: HONSINGER V. STATE AND THE NEED FOR

FlexibILITY IN THE RUles of REAL PROPERTY .....................

Mental Health Land Trust Litigation: State $v$. WeIsS and Its Aftermath,

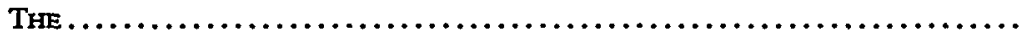

ROSENBERG V. SMIDT. DRAMATIC RAMIFICATIONS FOR NONJUDICIAL

Foreclosure Sales in Alaska $\ldots \ldots \ldots \ldots \ldots \ldots \ldots \ldots \ldots \ldots \ldots \ldots$

Standing to Challenge the Disposition of Land in Alaska: A Proposed

REMEDY FOR THE INADEQUACIES IN THE CURRENT CASE LAW............. 2:393

Struggle for Alaska's Submerged Lands, The .....................

WANBERG V. WANBERG. Characterization OF Property For the PURPOSE OF

EQUitable Distribution $\ldots \ldots \ldots \ldots \ldots \ldots \ldots \ldots \ldots \ldots \ldots \ldots \ldots \ldots \ldots$

\section{REMEDIES}

Alaska's Apportionment of Damages Statute: Problems for Litigants .... Alaska's Public Duty Exception: Restraints Upon tHE Right TO

Contractual IndEMNITY ................................. 3:331

Eidelson v. ARcher: Exhaustion of Remedies in a Private Hospital ....... 1:277

Evaluation of Earnings Loss in Alaska Courts, The Implications of

BEAULIEU AND GUINN, THE ................................ 2:311

MUNICIPALITY OF ANCHORAGE V. HITACHI CABLE, LTD.-TMME FOR ADOPTION OF

a Vold Contract Remedy for Alaska Public Contracting Authorimes..

Survey of Federal Tax Collection Procedure: Rights and Remedies of

TAXPayers AND the InTERNAL ReVEnUE SERVice, A .................. 3:269

Tort Loss Allocation Among Jont Tortfeasors in Alaska: A Call for

Comparative Contribution . ................................. 2:127

SECURITIES LAW

Constitutionality of Alaska's Takeover Bid Disclosure ACt, The ........ 
Defining an "InVestment Contract" for Purposes of Alaska Blue Sky Law: Have the Alaska Courts Stretched Their Test Beyond

Meaningful Application?

\section{SENTENCING}

Development of Appellate Sentencino in Alaska, The .............. $7: 265$

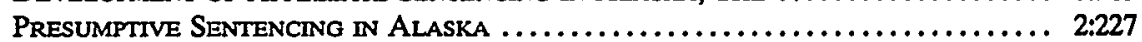

Prison Overcrowding in Alaska: A legislative Response to the CLEARY

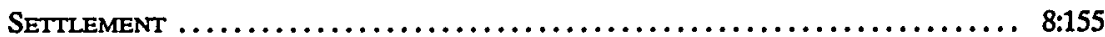

TAX

Survey of Federal Tax Collection Procedure: Ryohts and Remedies of

TAXPAyers ANd the INTERnal ReVenue SERVICE, A .................. 3:269

Taxing Issue: Are Limited Entry Fishing Permits Property?, A.......... 9:93

TORTS

Abandonment v. Adoption: Terminating Parental Rights and the Need FOR DISTINCT LEGAL INQUIRIES .

Alaska's Apportionment of Damages Statute: Problems for Litioants .... $\quad 9: 1$

Alaska's Medical Malpractice ExPert Advisory PaNel: Assessing the

PROGNOSIS.

Alternative Dispute Resolution Strategies in Medical Malpractice . . . . 9 9:429

Analysis of Jurisdictional Issues Presented When State-Employed

SEAMEN ARE INJUREd AND SEEK REDRESS, AN

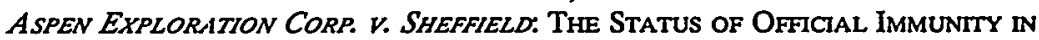
Alaska ..............................................

Bad Samaritans Make Dangerous Precedent. The Perils of Holdino an

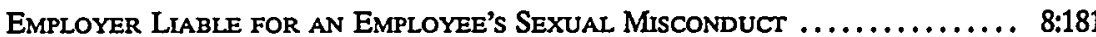

Construction and Admissibility of Insurance Policies That Provide Coverage for Punittve Damage Awards, The $\ldots \ldots \ldots \ldots \ldots \ldots \ldots \ldots$

Damages for a Decedent's Pre-IMPACT Fear: AN Element of Damages UNDER AlASKa's SURVIVORShIP STATUTE $\ldots \ldots \ldots \ldots \ldots \ldots \ldots \ldots \ldots \ldots \ldots$

Damages for Wrongful Death in Alaska ........................

Defining "Recikless Disregard" In Defamation Sutts: The Alaska Supreme COURT Renders a Narrow INTERPretation OF tHE NEW YORK TMMES RULE. Employment At Will in Alaska: The Question of Public Policy Torts..... Evaluation of Earnings loss in Alaska Courts: The Implications of

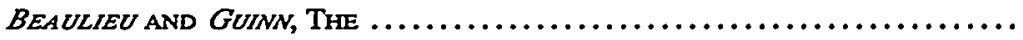

LIABILITY OF THE STATE AND ItS EMPLOYEeS FOR tHE NEgLIGENT INVESTIOATION of Child Abuse Reports . ................................. 10:401

Limits of Liability: Can Alaska OIl SPIll VictTMS Recover PuRE Economic Loss? ...................................................

Negligence Per $S E$ and Broad Statutory Construction in Alaska: The Adoption of an Applicable Statute as an Appropriate Standard of CARE $10: 87$

Products LIabil ITY IN Alaska — A Practitioner's Overview $\ldots \ldots \ldots \ldots$

SeAt Belt Issue: Judicial DisRegard for Legislative ACTION, The......... SOVEREIGN IMMUNITY AND THE DISCRETIONARY FUNCTION EXCEPTION OF THE

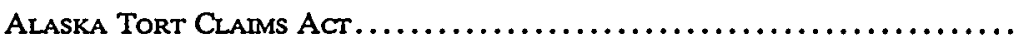
Tort loss allocation Among Joint Tortfeasors in Alaska: A Call for Comparative Contribution...$\ldots \ldots \ldots \ldots \ldots \ldots \ldots \ldots \ldots \ldots \ldots \ldots \ldots$

\section{WORKERS' COMPENSATION}

Alaska Workers' Compensation LaW: Fact-Finding, Appellate Review and the Presumpiton of Compensability, The 
VOLUME \& PAGE

SOMETHING More IMPORTANT Than MONEY-Vocational ReHabilitation IN

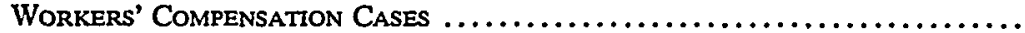

\section{AUTHOR INDEX TO ARTICLES AND COMMENTS}

VOLUME \& PAGE

BaIRd, Ronald L., Easement Condemnation and State v. Doyle: Fair Market Value Without a Market.

Black, Kathryn A., David H. Bundy, Cynthia Pickering Christianson and Cabot Christianson, When Worlds Collide: Alaska Native Corporations and the Bankruptcy Code ...............................................

Bankston, William M. and Steven T. O'Hara, The Creation, Operation, and Dissolution of a Limited Partnership in Alaska .

Bederman, Davi F., High Stakes in the High Arctic: Jurisdiction and Compensation for Oil Pollution from Offshore Operations in the Beaufort Sea....

BRAdLEY, M. Katheryn and DeBorah L. WILlanMs, "Be It Enacted by the People of Alaska. .." - A Practitioner's Guide to Alaska's Initiative Law .......

Carns, Teresa White and John Kruse, $A$ Re-evaluation of Alaska's Plea

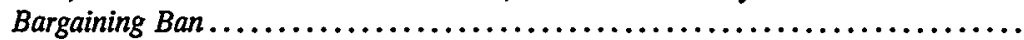

CROFT, ChANCY, Something More Important Than Money-Vocational Rehabilitation in Workers' Compensation Cases ..........................

Crook, Penny Lozon, Employment at Will: The "American Rule" and Its Application in Alaska ............................................

Crosby, Davm C., The Constitutionality of Sobriety Checkpoints in Alaska ........

Di Pietro, Susanne, The Development of Appellate Sentencing in Alaska .........

Di Pietro, Susanne, Foreward to Native Law Selections: Recent Developments in Federal Law as Applied to Native Alaskans ........................ 10:333

Di Pietro, Susanne, Tribal Court Jurisdiction and Public Law 280: What Role for Tribal Courts in Alaska? ...................................... 10:335

Feldman, Jefrerey M. and Stuart A. Ollanick, Compelling Testimony in Alaska: The Coming Rejection of Use and Derivative Use Immunity.

Fessler, Daniel William, The Alaska Corporations Code: The Forty-Ninth State Claims the Middle Ground ........................................

FITZGERALD, JOHN RichaRd, An Analysis of Jurisdictional Issues Presented When State-Employed Seamen Are Injured and Seek Redress.

FosSEY, W. RICHARD, Employment Discrimination Law-Strand v. Petersburg Public School and Fridriksson v. Alaska USA Federal Credit Union: The Supreme Court Charts an Uncertain Course ........................

Fossey, W. RichaRD, Meiners v. Bering Strait School District and the Recall of Public Officers: A Proposal for Legislative Reform ....................

Fossey, W. RrchaRd AND JoHn M. SEDOR, In re Copper River School District: Collective Bargaining and Chapter 9 Municipal Bankruptcy .................

Frost, JR., DoN J., Amoco Production Co. v. Village of Gambell and Motor Vehicle Manufacturers Association v. State Farm Mutual Automobile Insurance Co.: Authority Warranting Reconsideration of the Substantive Goals of the National Environmental Policy Act.

GREEN, SteVEn KeITH, Freedom of Religion in Alaska: Interpreting the Alaska Constitution

Holloman, Duncan, The Struggle for Alaska's Submerged Lands ............ 5:69

INGRAFAM, MiLlaRd F., Damages for Wrongful Death in Alaska ............. 5:293

JoNEs, G. KEVIN, Major Issues in Developing Alaska's Outer Continental Shelf Oil and Gas Resources. 
Keyes, LAUREnce, Alaska's Apportionment of Damages Statute: Problems for

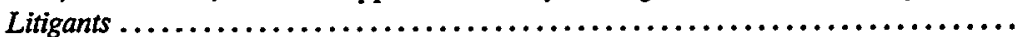

KNUTH, MARGOT O., Inspection and Discovery of State Records in Alaska........

Larsion, ARTHur and JoHn LewIs, The Alaska Workers' Compensation Law: Fact-

Finding, Appellate Review, and the Presumption of Compensability ............

Matthews, Thomas A., Products Liability in Alaska-A Practitioner's Overview ..

MCCUNe, BlaIR, Overview of Juvenile Delinquency Law in Alaska, An ..........

MCCUNE, BLAIR, Self-Incrimination Protection Under the Alaska Constitution: $A$

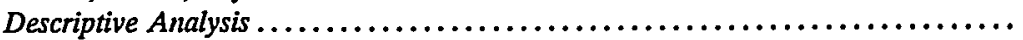

MCGreal, Paul E., A Tale of Two Courts: The Alaska Supreme Court, the United

States Supreme Court, and Retroactivity.......................... 9:305

Metzloff, Thomas B., Alternative Dispute Resolution Strategies in Medical

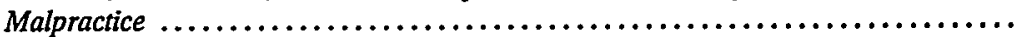

Moberly, Michael D., Philip J. Moberly and LaURa L. Farley, Walt-zing

Through an Employment Termination: Is There a Duty to Investigate Before

Discharging in Alaska ................................... 11:231

Nelson, Ronald L., Welcome to the "Last Frontier," Professor Gardner: Alaska's

Independent Approach to State Constitutional Interpretation .................

Noble, HeATHER, Tribal Powers to Regulate Hunting in Alaska................

Nordstrand, Scott J. ANd Paul D. SEyFerth, Private Rights Versus Public

Power: The Role of State Action in Alaska Constitutional Jurisprudence..........

Osowski, Shane J., Alaska Distress Law in the Commercial Context: Ancient Relic or Functional Remedy? .........................................

PARKs, RICHARD W., Evaluation of Earnings Loss in Alaska Courts: The

Implication of Beaulieu and Guinn

Pengilly, Charles R., Post-Plea Appeal of "Dispositive" Issues: "There's Glory

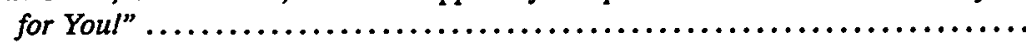

Pengilly, Charles R., Restitution, Retribution and the Constitution.............

Quarles, Steven P. AND Thomas R. Lundouist, The Alaska Land Act's

Innovations in the Law of Access Across Federal Lands: You CAN Get There from

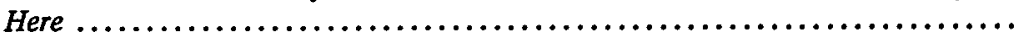

QuINN, EMILY D., Standards of Materiality Governing the Prosecutorial Duty to Disclose Evidence to the Defense ...............................

SEYFERTH, PAUL D., The Construction and Admissibility of Insurance Policies that Provide Coverage for Punitive Damage Awards .........................

StEBING, DAvid G., Insurance Regulation in Alaska: Healhy Exercise of a State

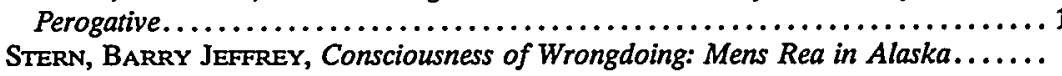

Stern, BARRy JefFrey, Presumptive Sentencing in Alaska ...................

Sutherland, EARL M., One Client, One Defense: Revisiting CHI with the Alaska

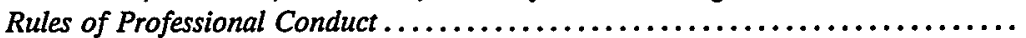

Wilkens, James K. And Thomas A. Matthews, A Survey of Federal Tax

Collection Procedure: Rights and Remedies of Taxpayers and the Internal Revenue

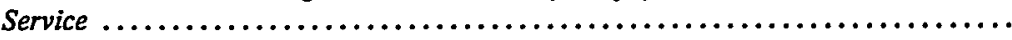

STRICKLAND, SHERIDAN, Municipality of Anchorage v. Hitachi Cable, Ltd.-Time for Adoption of a Void Contract Remedy for Alaska Public Contracting Authorities.

WHTte, StePHEN M., "Equal Access" to Alaska's Fish and Wildlife .............. 11:277

Wise, Michael B., Northern Lights-Equal Protection Analysis in Alaska ....... $3: 1$

Zaleha, D. Bernard, Alaska's Criminalization of Refusal to Take a Breath Test: Is It a Permissible Warrantless Search Under the Fourth Amendment? .......... 


\section{AUTHOR INDEX TO NOTES}

VOLUME \& PAGE

AввоTт, SUSAN K., Liability of the State and Its Employees for the Negligent

Investigation of Child Abuse Reports ........................... 10:401

Altes, Scott LAURence, The Statute of Limitations for Professional Malpractice in Alaska After Lee Houston \& Associates, Ltd. v. Racine ......................

Antipolo, Virginia Cella, The Impact of Economic Incentives on the Award of Attorney's Fees in Public Interest Litigation ........................ 1:189

ARONIE, JonAthan Scotr, Alaska's Medical Malpractice Expert Advisory Panel; Assessing the Prognosis.

Aviles, Karen A., Eidelson v. Archer: Exhaustion of Remedies in a Private Hospital

BAKER, C. MARK, Riley v. Northern Commercial: Commercial Rationale Triumphs Over Statutory Interpretation

BALUSS, JANE, Mandatory Mediation of Coastal Zone Planning Disputes in

Alaska-An Innovative Approach to Administrative Decisionmaking ............

Bostzeman, William L., Aspen Exploration Corp. v. Sheffield: The Status of Official Immunity in Alaska...

Brumbaugh, Karen B., Wanberg v. Wanberg: Characterization of Property for the Purpose of Equitable Distribution.

BRUYNES, IRENE W., Strict Liability and the Admissibility of Evidence of Subsequent Remedial Measures Under Evidence Rule 407.

ButT, JefFrey Drew, Indian Child Welfare Act: Does It Cover Custody Disputes Among Extended Family Members?

CARroli, ROBERT, Litigation-Ending Sanctions: Alaska Courts' Use of Rule $37 . .$.

Castellon, Michael C., Standing to Challenge the Disposition of Land in Alaska: A Proposed Remedy for the Inadequacies in the Current Case Law .............

Clapacs, Grantzand M., "When in Nome...": Custom, Culture and the Objective Standard in Alaskan Adverse Possession Law.

Clark, B. NeIl S., Shareholders' Agreements in Alaska After Hikita v. Nichiro Gyogyo Kaisha, Ltd.

CoHEN, Joel MrCHAEl, Nitz v. State: Skewing the Evidentiary Rules to Prosecute

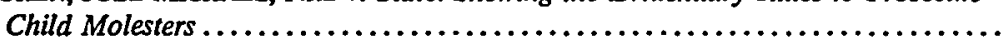

Collins, Jefrrey D., Alaska Rule 26: A Quixotic Venture Into the World of Mandatory Disclosure

CoOK, RJChard N., Drug Testing of Public and Private Employees in Alaska......

Cureton, Frank W., The Reportorial Power of the Alaska Grand Jury ...........

Davis, Thomas P., Civil Rule 90.3: Judicial Discretion Under Alaska's Child Support Guideline 3:295

DEBusk, SusAN E., Alaska's Insanity Defense and the "Guilty but Mentally Ill" Verdict.

DosIER, DENISE, The Clouds Are Lifting: The Problem of Title to Submerged Lands in Alaska

EISENSCHMIED, NANCY L, Lesser-Included Offenses in Alaska: State v. Minano ....

ERB, JASON R., The Implied Covenant of Good Faith and Fair Dealing in Alaska: One Court's License to Override Contractual Expectations .................

FISHEL, Alan, Pears v. State: An Improper Application of Alaska's Current Law to Intoxicated Drivers ...........................................

Flynn, MrChael L., Police Deception of a Criminal Suspect's Attorney: An Analysis of Moran v. Burbine Under the Alaska Constitution.

Frank, RICHARD A., Negligence Per Se and Broad Statutory Construction in Alaska: The Adoption of an Applicable Statute as an Appropriate Standard of Care 
Frost, JR., Don J., Preliminary Injunctions as Relief for Substantial Procedural Violations of Environmental Statutes: Amoco Production Co. v. Village of Gambell .......................................... 4:105

GrEENE, DAVD A., Investigative Stops in Alaska: Can Coleman Survive a Multifactored Balance?

Grossbauer, John F., Alaska's Right to Privacy Ten Years After Ravin v. State: Developing a Jurisprudence of Privacy........................ 2:159

Gustafson, MaRK D., Custodial Consents to Search in Alaska: A Waiver Approach, at Least Where Miranda Warnings Are Absent? .............. 3:125

Hammar, Julian E., Breaking the Age Barrier in Alaska: Including Adult Children

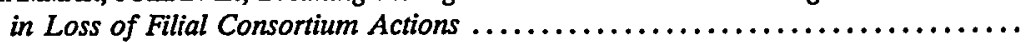
Hardgrove, SANDra J., Local Hire Laws: Alaska's Futile Attempts at Preferential

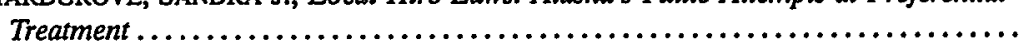

HARRINGTON, ROBERT E., Alaska's Public Duty Exception: Restraints upon the

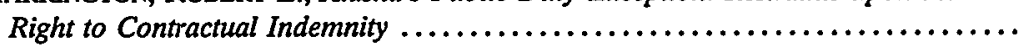

HARrison, Lou, Hammond v. North Slope Borough: The Endangered Species

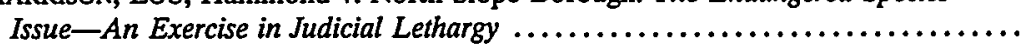

Harrison, Lou, Managing Sensitive Ecosystems: Honsinger v. State and the Need

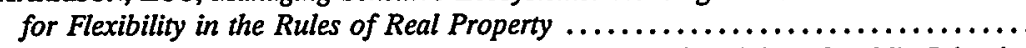

HEADley, DaraH S., The Alaska Supreme Court and the Rights of Public School Teachers as Employees: A Suggested Response to Judicial Limitation of Collective

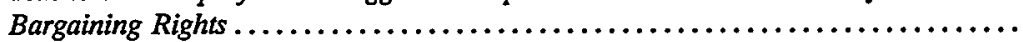

HeMMerich, Michael R., The Constitutionality of Alaska's Takeover Bid

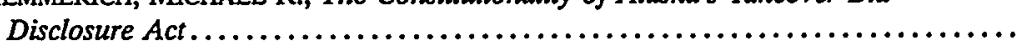

Johnson, ElizA.BetH A., Alaska Pacific Assurance Co. v. Brown: The Right to Travel and the Constitutionality of Continuous Residency Requirements .......... Jones, Celia Grasty, Nelson v. Nelson: A Proposal for Equitable Distribution of

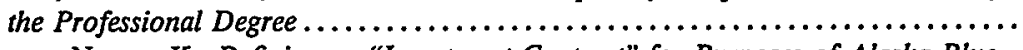

Jones, NANCY K., Defining an "Investment Contract" for Purposes of Alaska Blue Sky Law: Have the Alaska Courts Stretched Their Test Beyond Meaningful

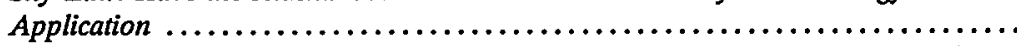

KAPLAN, JOHN STUART, The Mental Health Land Trust Litigation: State v. Weiss

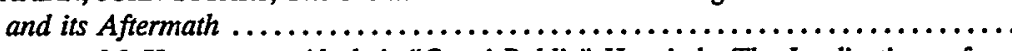

KENYON, M. KATHLEEN, Alaska's "Quasi-Public" Hospitals: The Implications of Storrs ............................................ 2:185

KORDZIEL, KeVIN M., Rule 82 Revisited: Attorney Fee Shifting in Alaska......... 10:429

KORNFIELD, PHOEBE, The Enforceability of Forum-Selection Clauses After Stewart Organization, Inc. v. Ricoh Corporation ...................... 6:175

KuRTz, M. DAVm, Managing Alaska's Coastal Development: State Review of Federal Oil and Gas Lease Sales .................................. 11:377

Lam, Brian E., The Admissibility of Prior Bad Acts in Sexual Assault Cases Under Alaska Rule of Evidence 404(b)_An Emerging Double Standard ........... 5:193

Leatherwood, Leslie A., Sanity in Alaska: A Constitutional Assessment of the Insanity Defense Statute.................................. 10:65

Lews, Davm P., The Limits of Liability: Can Alaska Oil Spill Victims Recover

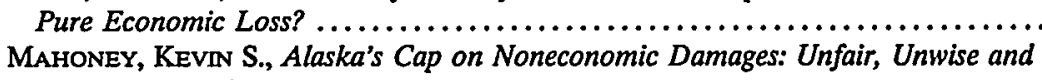

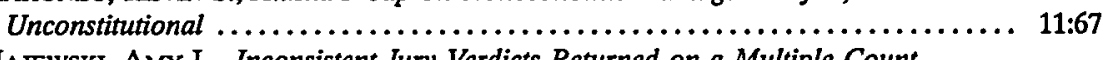

MAJEWSKI, AMY L., Inconsistent Jury Verdicts Returned on a Multiple Count Indictment of a Single Defendant

MARINACcio, LeONARD, III, Out on Parol?: A Critical Examination of the Alaska Supreme Court's Application of the Parol Evidence Rule................ 11:405 MASON, Gary EDWARD, Lawrence v. Lawrence: The Use of Rule 60(b) Motions Based upon Post Judgment Changes in Controlling Law 
VOLUME \& PAGE

Meyer, JeAnNe ANd Jim O. Stuckey, II, Deterring Defendants from Taking the

Stand: The Extension of State v. Wickham to Rule 404(b) .................. 8:291

Mills, David Edward, Tort Loss Allocation Among Joint Tortfeasors in Alaska: A

Call for Comparative Contribution ..............................

Nazarian, Douglas R., Catholic Social Services, Inc. v. C.A.A.: Best Interests and

Statutory Construction of the Indian Child Welfare Act ................ 7:203

Nelson, Christopher D., Toward a Compensatory Model of Alimony in Alaska .. 12:101

Orgill, Marcia Swihart and Bellanne Meltzer Toren, Sovereign Immunity and the Discretionary Function Exception of the Alaska Tort Claims Act ........ 2:99

OWens, Thomas P., III, Employment at Will in Alaska: The Question of Public Policy Torts

Peterson, Thomas W., Doctrine of the Implied Insured in Alaska: Recent

Developments Concerning Third Parties to Insurance Contracts ...............

PetTT, Kenton K., The Waiver of Tribal Sovereign Immunity in the Contractual Context: Conflict Between the Ninth Circuit and the Alaska Supreme Court?..... 10:429

Puissey, Steven D., Compulsory Joinder of Partial Subrogees: Implications of the Alaska Rule.

READ, John R., Thomas v. Anchorage Telephone Utility: Alaska Tackles Gender-

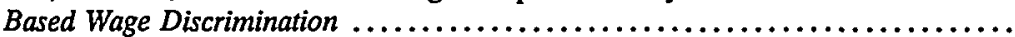

REDMILES, MARK A., Shelter from the Storm: The Need for Wrongful Discharge Legislation in Alaska

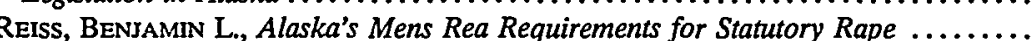

RoBb, Cliona MARy, Bad Samaritans Make Dangerous Precedent: The Perils of Holding an Employer Liable for an Employee's Sexual Misconduct .............

Rowe, JAmes S., Protection of Child Witnesses and the Right of Confrontation: $A$ Balancing of Interests.............................................

RUTLEDge, JOYCE S., Monitoring the Employment Contract in Alaska ...........

Simon, Jeremy S., Privacy v. Practicality: Should Alaska Adopt the Leon Good Faith Exception? .......................................... 10:143

Smrth, LAURENCE S., A Proposed Solution to the Federal Taxation of Alaska Permanent Fund Dividend Payments ...............................

Stark, Sanford Wert, Abandonment v. Adoption: Terminating Parental Rights and the Need for Distinct Legal Inquiries

Stegemoeller, Andrew B., Defining "Reckless Disregard" in Defamation Suits.

The Alaska Supreme Court Renders a Narrow Interpretation of the New York

Times Rule................................................

StEIN, TERrI, The Seatbelt Issue: Judicial Disregard for Legislative Action .........

Strauss, PhIlip Reed, Control and/or Misconduct: Clarifying the Test for Piercing

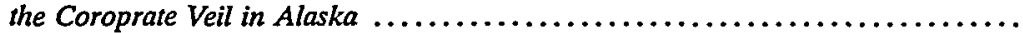

Sydnor, Thomas D., II, Damages for a Decedent's Pre-impact Fear: An Element of Damages Under Alaska's Survivorship Statute .........................

Thesing, JR., W. Joseph, Alaska Rule of Civil Procedure 11: A Proposed Amendment and a Guide for Application and Interpretation .................

TrIBble, Bradford J., Prison Overcrowding in Alaska: $A$ Legislative Response to the Cleary Statement .......................................

WARREN, PAtricia J., Rosenberg v. Smidt: Dramatic Ramifications for Nonjudicial Foreclosure Sales in Alaska? .................................. 5:357

Weiss, Jon David, A Taxing Issue: Are Limited Entry Fishing Permits Property? .. 9:93

Williams, Carol R., A Proposal for Protecting Privacy During the Information Age ...................................................... 11:119

WrTzLEBEN, BEA, Visitation Rights for Natural Parents After Stepparent Adoption .. 1:319

Woods, Michele J., The Adoption of the ABA Standards for Imposing Lawyer Sanctions by the Alaska Supreme Court-In re Buckalew 